\title{
UJI EFEK PEMBERIAN EKSTRAK ETANOL 70\% BIJI BUAH TERUNG UNGU (SOLANUM MELONGENA L.) TERHADAP KADAR KOLESTEROL HDL SERUM DARAH TIKUS PUTIH JANTAN (RATTUS NORVEGICUS) GALUR WISTAR
}

\author{
Baiq Nova fajriyatun, EM Sutrisna, Dona Dewi Nirlawati \\ Dosen Fakultas Kedokteran Universitas Muhammadiyah Surakarta
}

\begin{abstract}
Extract of eggplant fruit (Solanum melongena L.) seed is a plant that has anti-hypercholesterolemia effect on the state of dyslipidemia. One of the compounds contained in them are flavonoids nasunin which can increase levels of HDL cholesterol (high density lipoprotein). HDL cholesterol is considered as a compound have the ability to remove excess cholesterol from the arteries, and therefore called good cholesterol. This study is a laboratory experimental research using pretest and posttest control group. The sample consisted of 25 rats were divided into 5 groups. Group I is a negative control (-), Group II is a positive control (+), group III was treated 1 (dose 1), group IV was treated 2 (dose 2), and V is the treatment group 3 (dose 3). Each group was given a high-cholesterol diet. Negative and positive control group were not given the extract of fruit seed of eggplant, the treatment groups III, IV, and V were given the extract of fruit seed of eggplant with each dose of $20 \mathrm{mg} / \mathrm{kg}, 40 \mathrm{mg} / \mathrm{kg}, 80 \mathrm{mg} / \mathrm{kg}$ were given for 4 weeks. HDL cholesterol levels will be measured before and after cholesterol diet and calculated each week after giving of the extract. The data obtained tested with statistical tests One-Way Anova. HDL cholesterol positive control group and the treatment group showed significant differences between groups. Treatment groups 1 and 2 levels of HDL cholesterol lower than the positive control group and the treatment group 3. Extract of eggplant fruit seed dose of $80 \mathrm{mg} / \mathrm{kg}$ show an increase in $H D L$ cholesterol levels were significantly $(p<0.05)$. The $70 \%$ ethanol extract of eggplant fruit seed at a dose of $80 \mathrm{mg} / \mathrm{kg}$ can increase HDL cholesterol levels significantly.
\end{abstract}

Keywords : extract of eggplant fruit seed, hypercholesterol, HDL cholesterol

\section{PENDAHULUAN}

Penyakit Jantung Koroner (PJK) salah satu akibat dari perilaku masyarakat negara modern dan pola hidup modern. Hal ini disebabkan karena penyebab penyakit jantung berkaitan dengan keadaan dan perilaku masyarakat maju misalnya tingginya stress, salah makan, dan gaya hidup modern seperti rokok dan minum alkohol yang berlebihan (Bustan, 2007).

Makanan siap saji atau fast food banyak mengandung sodium, natrium, lemak jenuh dan kolesterol. Sodium dan natrium merupakan bagian dari garam. Asupan natrium berlebihan, dapat mengakibatkan kekurangan kalium sehingga terjadi penurunan fungsi otot jantung dan kelambatan proses penghantaran rangsangan saraf, yang meningkatkan aliran dan tekanan darah sehingga menyebabkan tekanan darah tinggi. Tekanan darah tinggi dapat berpengaruh munculnya gangguan penyakit jantung. (Apriadji, 2007).

Pada beberapa studi epidemiologis yang dilakukan menunjukkan adanya hubungan erat antara penurunan kadar kolesterol HDL (high density lipoprotein) dengan risiko PJK (penyakit jantung koroner) dimana kolesterol HDL (high density lipoprotein) memiliki peran yang sangat penting pada keadaan dislipidemia (Castelli, W.P., et al., 1977). 
Dislipidemia merupakan kelainan metabolisme lipid yang ditandai dengan peningkatan atau penurunan fraksi lipid dalam plasma. Kelainan fraksi lipid yang utama adalah kenaikan kadar kolesterol total, kolesterol LDL (low densit lipoprotein), dan trigliserida serta penurunan kadar kolesterol HDL (high density lipoprotein) (Adam, 2009).

Peningkatan kadar high density lipoprotein (HDL) telah muncul sebagai target terapi baru yang potensial untuk pengobatan penyakit jantung. Dimana peran HDL (high-density lipoprotein) sendiri sebagai pembawa kolesterol bebas berlebih di jalur transpor balik kolesterol yang diyakini untuk memberikan perlindungan terhadap aterosklerosis (Brewer, 2004).

Terung ungu merupakan salah satu tumbuhan yang diindikasikan untuk pengobatan beberapa penyakit, termasuk diabetes, arthritis, asthma, dan bronchitis. Beberapa penelitian memiliki bukti bahwa ekstrak terung ungu mempunyai efek yang signifikan terhadap penurunan tekanan darah dan kolesterol hati pada manusia (Khan 1997; Jorge et al. 1998) (Magioli dan Mansur, 2005).

Penelitian lain yang dilakukan pada manusia dilakukan oleh Angel Roffo (1943), Argentina dan di Brazil oleh Cruz et al (1998) menunjukkan bahwa tanaman ini memiliki efek penurun lipid, penelitian menggunakan terung dengan jus jeruk. Studi penelitian lain yang dilakukan di laboratorium hewan (Kritchevsky et al 1.975;.Sudheesh et al, 1997; Jorge Ribeiro et al 1998), menunjukkan peran untuk hipolipidemik pada Solanum melongena L. Studi lain kembali dilakukan dimana tidak ada perbaikan lipidemia (Silva et al. 1999) (Goncalves, et al., 2006).

Namun, pada beberapa penelitian yang dilakukan terhadap terung ungu tidak menunjukkan adanya peningkatan yang signifikan terhadap kadar kolesterol HDL (high density lipoprotein), meskipun telah dilaporkan bahwa terung ungu memiliki efek hipolipidemik.

Berdasarkan hal di atas, perlu dilakukan penelitian lebih lanjut menggunakan ekstrak etanol $70 \%$ biji buah terung ungu untuk meneliti apakah biji buah terung ungu memiliki pengaruh terhadap kadar kolesterol HDL(high density lipoprotein) pada tikus putih.

\section{METODE PENELITIAN}

Penelitian ini merupakan penelitian eksperimental laboratorik dengan pendekatan pretest dan postest control group dengan alokasi random yang mempelajari efek ekstrak etanol biji terung ungu terhadap kadar kolesterol HDL pada tikus putih jantan. Penelitian ini dilaksanakan di Laboratorium Farmakologi Fakultas Kedokteran dan di Fakultas Ilmu Kesehatan Universitas Muhammadiyah Surakarta pada bulan Oktober 2012.

Populasi yang digunakan dalam penelitian ini berupa tikus putih (Rattus norvegicus) jantan berumur 2-3 bulan, dengan berat badan 150200 gram. Besar sampel ditentukan berdasarkan panduan penelitian WHO yaitu minimal 5 ekor tikus tiap kelompok. Dalam penelitian ini tikus dibagi menjadi 5 kelompok, sehingga didapatkan jumlah sampel tiap kelompok sebanyak 5 ekor. Untuk mengantisipasi terjadinya drop out maka jumlah sampel diperbesar menjadi 6 ekor tiap kelompok, sehingga diperoleh jumlah sampel keseluruhan 30 ekor. Dengan kriteria inklusi yaitu tikus putih jantan (Rattus norvegitus) galur Wistar, sehat dan mempunyai aktivitas normal, berumur 2-3 bulan, berat badan 150-200 gr. Sedangkan kriteria ekslusi yaitu tikus dengan kondisi fisik terlihat cacat dan tikus yang mati. Data hasil pengukuran kadar kolesterol HDL kemudian dianalisis menggunakan uji statistik, yaitu:1. Uji statistik Shapiro Wilk, untuk menguji distribusi data yang didapat dengan jumlah sampel sedikit (kurang dari 50);2. Uji statistik Test of Homogenety of Variences, untuk menguji homogenitas dari varian data tiap kelompok; 3 . Uji statistik One-way Anova, untuk menguji rata-rata perbandingan data tiap kelompok.;4. Uji statistik LSD (Least Significant Difference), untuk menguji signifikasi dari perbedaan ratarata data antar kelompok perlakuan.Jika $\mathrm{p}<0,05$ maka H0 ditolak dan $\mathrm{H} 1$ diterima.

\section{HASIL DAN PEMBAHASAN}

Pada penelitian ini dilakukan menggunakan lima kelompok. Kelompok I sebagai kontrol negatif (aquades), kelompok II sebagai kontrol positif (simvastatin), kelompok perlakuan III, IV, dan V. Untuk dosis pada ketiga kelompok perlakuan didapatkan dari uji orientasi, dimana didapatkan kelompok perlakuan $\mathrm{III}=20 \mathrm{mg} / 200 \mathrm{grBB}$, kelompok perlakuan IV = $40 \mathrm{mg} / 200 \mathrm{grBB}$, dan kelompok perlakuan $\mathrm{V}=80$ $\mathrm{mg} / 200 \mathrm{grBB}$. 
Pada penelitian ini untuk menginduksi keadaan dislipidemia (hiperkolesterol) pada tikus digunakan propiltiourasil $0,01 \%$ dan diet tinggi kolesterol, yang terdiri dari pakan standar ditambahkan kuning telur bebek, minyak kelapa, dan lemak kambing. Keadaan dislipidemia diketahui dengan cara membandingkan kadar kolesterol HDL tikus sebelum diberi diet tinggi kolesterol (minggu 1) dan sesudah diberi diet tinggi kolesterol (minggu 2). Hasil analisis menunjukkan bahwa kondisi awal atau sebelum perlakuan dan setelah pemberian diet tinggi kolesterol dan propiltiourasil $0,01 \%$ terdapat perbedaan kolesterol HDL yang bermakna antar kelompok.

\begin{tabular}{llllll} 
Tabel 1. & Hasil uji statistik & One-Way Anova minggu 1 dan 2 \\
\hline & Sum of Squares & df & Mean Square & F & Sig. \\
\hline Between Groups & 229.250 & 6 & 20.618 & 1.619 & .009 \\
\hline Within Groups & 123.710 & 18 & 12.736 & & \\
\hline Total & 352.960 & 24 & & & \\
\hline
\end{tabular}

Hasil pengukuran kadar kolesterol data memperlihatkan bahwa pada kelompok kontrol negatif kadar kolesterol HDL mengalami penurunan data yang tidak konstan, sedangkan pada kelompok kontrol positif dan perlakuan menunjukkan data yang tetap konstan. Untuk melihat hasil efek yang ditimbulkan pada pemberian ekstrak biji buah terung ungu maka pengujian statistik dimulai dengan membandingkan data pada kelompok kontrol positif dan kelompok perlakuan pada minggu ke-2 (post induksi) sampai minggu ke6. Hasil pengujian statistik pada kelompok II (kontrol positif) sampai kelompok V (kelompok perlakuan) didapatkan distribusi data normal dan data homogen pada minggu ke-2 (post induksi) sampai minggu ke-6. Kemudian dilanjutkan dengan uji LSD didapatkan hasil perbedaan yang bermakna pada semua kelompok pada tiap minggu .

Kadar kolesterol HDL pada kelompok kontrol negatif relatif menurun dibandingkan dengan kelompok kontrol positif dan kelompok perlakuan. Penurunan kadar kolesterol HDL ini disebabkan oleh kerja propiltiourasil yang bekerja sebagai antitiroid yang dapat menghambat sel-sel tiroid pada tikus untuk memproduksi hormon tiroid. Penghambatan sintesis hormon tiroid oleh propiltiourasil dapat meningkatkan kadar kolesterol dalam darah.

Ekstrak etanol $70 \%$ buah biji terung ungu dengan dosis $20 \mathrm{mg} / 200 \mathrm{grBB}, 40$ $\mathrm{mg} / 200 \mathrm{grBB}$, dan $80 \mathrm{mg} / 200 \mathrm{grBB}$ mempunyai efek meningkatkan kadar HDL pada serum darah tikus putih yang mulai terlihat pada minggu ke-3(minggu pertama setelah post induksi atau minggu pertama pemberian ekstrak), minggu ke-4, minggu ke-5, dan minggu ke-6. Pada kelompok kontrol negatif dan kontrol positif terdapat perbedaan bermakna $(p<0,05)$ pada setiap minggu, hal ini menunjukkan bahwa adanya efek peningkatan kadar kolesterol HDL pada penggunaan preparat simvastatin dengan dosis $0,72 \mathrm{mg} / 200 \mathrm{grBB} /$ hari. Perbedaan bermakna juga didapatkan pada kelompok kontrol negatif dengan kelompok perlakuan atau kelompok dosis I (20 mg/200grBB), kelompok dosis II (40 $\mathrm{mg} / 200 \mathrm{grBB})$, dan dosis III $(80 \mathrm{mg} / 200 \mathrm{grBB})$ mulai terlihat peningkatan kadar kolesterol HDL pada minggu ke-3. Hal ini menunjukkan bahwa pada dosis $20 \mathrm{mg} / 200 \mathrm{grBB}$ sudah mampu meningkatkan kadar kolesterol HDL dibandingkan dengan kontrol negatif.

Signifikansi data pengukuran kadar kolesterol pada kelompok kontrol positif dan kelompok perlakuan mulai menunjukan perbedaan yang signifikan. Data pada kelompok kontrol positif (kelompok II) menunjukkan nilai $\mathrm{p}=0,000$. Data untuk dosis $20 \mathrm{mg} / 200 \mathrm{grBB}$ (kelompok III) menunjukkan $\mathrm{p}=0,000$. Data dosis $40 \mathrm{mg} / 200 \mathrm{grBB}$ (kelompok IV) nilai $\mathrm{p}$ menunjukkan $\mathrm{p}=0,000$. Dan data untuk dosis $80 \mathrm{mg} / 200 \mathrm{grBB}$ (kelompok V) menunjukan nilai $\mathrm{p}=0,000$.

Perbandingan pada kelompok perlakuan III pada dosis $20 \mathrm{mg} / 200 \mathrm{grBB}$ menunjukkan perbedaan bermakna pada peningkatan kolesterol HDL pada minggu ke-2 sampai minggu ke-6. Data pada kelompok IV dengan dosis $40 \mathrm{mg} / 200 \mathrm{grBB}$ menunjukkan perbedaan bermakna pada tiap minggu terhadap peningkatan kolesterol HDL. Begitu juga dengan kelompok 
$\mathrm{V}$ menunjukkan data terdapat prbedan bermakna pada tiap kelompok pada minggu ke-2 (post induksi) sampai minggu ke-6.

Dapat disimpulkan bahwa kelompok yang diberikan perlakuan dengan dosis 80 mg/200grBB mempunyai efek peningkatan kadar kolesterol HDL lebih baik dibandingkan dengan dosis $20 \mathrm{mg} / 200 \mathrm{grBB}$ dan $40 \mathrm{mg} / 200 \mathrm{grBB}$, karena pada dosis $80 \mathrm{mg} / 200 \mathrm{grBB}$ mempunyai mean penurunan kadar kolesterol HDL lebih tinggi dari pada dosis $20 \mathrm{mg} / 200 \mathrm{grBB}$ dan 40 $\mathrm{mg} / 200 \mathrm{grBB}$. Efek ekstrak etanol $70 \%$ biji buah terung ungu dosis $80 \mathrm{mg} / 200 \mathrm{grBB}$ terhadap kadar kolesterol HDL sebanding dengan kelompok kontrol positif yang diberi preparat simvastatin $0,72 \mathrm{mg} / 200 \mathrm{grBB}$.

Berdasarkan hasil tersebut dapat membuktikan bahwa hipotesis pemberian ekstrak etanol $70 \%$ biji buah terung ungu mempunyai efek terhadap kadar kolesterol HDL pada serum darah tikus. Sesuai dengan penelitian sebelumnya yang menyatakan bahwa terung ungu menunjukkan efek peningkatan kadar kolesterol HDL.

Kelemahan pada penelitian ini yaitu tidak dilakukannya pemeriksaan pada kadar kolesterol LDL serum darah tikus putih untuk membandingkan apakah ada penurunan kadar kolesterol LDL dan peningkatan kadar kolesterol HDL. Menurut Sianipar dan Isnawati (2012), kolesterol LDL dan kolesterol HDL adalah dua jenis lipoprotein yang berkaitan dengan penyakit jantung. Kadar kolesterol LDL paling signifikan pada lipid darah yang meningkatkan rasio penyakit jantung sedangkan kadar kolesterol HDL memiliki fungsi yang berkebalikan dengan kolesterol LDL dalam penyakit jantung koroner.

\section{SIMPULAN}

Ekstrak etanol 70\% biji buah Terung Ungu (Solanum melongena L.) Dosis $20 \mathrm{mg} / 200 \mathrm{grBB}$, $40 \mathrm{mg} / 200 \mathrm{grBB}$ mempunyai efek terhadap peningkatan kadar kolesterol HDL pada serum darah tikus. Dan dosis $80 \mathrm{mg} / 200 \mathrm{grBB}$ yang memiliki peningkatan kadar kolesterol HDL pada serum darah paling tinggi. Ekstrak etanol ekstrak etanol $70 \%$ biji buah Terung Ungu (Solanum melongena L.) Dosis $80 \mathrm{mg} / 200 \mathrm{grBB}$ mempunyai efek yang sebanding dengan simvastatin dosis $0,72 \mathrm{mg} / 200 \mathrm{grBB}$ terhadap penurunan kadar kolesterol HDL pada serum darah tikus.

\section{DAFTAR PUSTAKA}

Adam, J.M.F., 2009. Dislipidemia, Dalam: Ilmu Penyakit Dalam Jilid III Edisi V. Jakarta : Interna Publishing.

Apriadji, H.W., 2007. Healthy Fast Food: Hidup Sehat Cpt. Jakarta: Gramedia Pustaka Utama. pp 12-13

Brewer, H.B, 2004. Increasing HDL Cholesterol Levels. The New England Journal of Medicine. NEng J Med. 350/15: 1491-1494

Bustan, M.N., 2007. Epidemiologi Penyakit Tidak Menular. Jakarta : Rineka Cipta.

Goncalves, M.C.R., Diniz, M., Melo, F.F., Dantas, Alexandre, H.G., Borba, J.D.C., 2006. Modest Hypolipidemic Effect Of Eggplant (Solanum Melongena L.) Dry Extract In Women With Dislipidemy, Under Nutritional Control. Rev. Bras. Farmacogn. 16:656-663

Magioli, C., Mansur, E., 2005. Eggplant (Solanum melongena L.): Tissue Culture, Genetic Transformation and Use as an Alternative Mpdel Plant. Acta Bot.Bras. 19:139-148

Castelli, W.P., Doyle, J.T., Gordon, T., Hames, C.G., Hjortland, M.C., et al., 1977. HDL Cholesterol And Other Lipids In Coronary Heart Disease The Cooperative Lipoprotein Phenotyping Study. Circulation. 55: 767-772

Silva, M., Santos, R.C., O'Leary, M.C., Santos, R.S., 1999. Effect of Aubergine (Solanum melongena) on Serum and Hepatic Cholesterol and Triglycerides in Rats. Arch. Biol. Technol. 42:339-342 